\title{
Prevalence of Overweight and Central Obesity in Uniderp University Medical Undergraduates
}

\author{
Felipe Cafure, José Schmidt, Lúcio Seabra Duré*, Pedro Henrique Furbeta, Rafael Moraes, \\ Rodrigo Arruda, Sandra Gaban
}

Medical School, Anhanguera Uniderp University, Campo Grande, Mato Grosso do Sul, Brazil

Email address:

lucioseabra@hotmail.com (L. S. Duré)

${ }^{*}$ Corresponding author

\section{To cite this article:}

Felipe Cafure, José Schmidt, Lúcio Seabra Duré, Pedro Henrique Furbeta, Rafael Moraes, Rodrigo Arruda, Sandra Gaban. Prevalence of Overweight and Central Obesity in Uniderp University Medical Undergraduates. Rehabilitation Science. Vol. 4, No. 4, 2019 , pp. 54-60. doi: $10.11648 /$ j.rs.20190404.11

Received: October 7, 2019; Accepted: November 5, 2019; Published: November 9, 2019

\begin{abstract}
The aim of this study is to evaluate the prevalence of overweight and central obesity among Anhanguera Uniderp School of Medicine undergraduates in the city of Campo Grande, state of Mato Grosso do Sul, and the possible related variables, according to socio-demographic data like life habits, and personal and family background. A cross-sectional quantitative observational study was conducted with a sample of 295 undergraduates who filled a survey questionnaire form, and Overweight and obesity were measured by using body mass index (BMI). Central obesity was measured by waist circumference: $\geq 88 \mathrm{~cm}$ for females and $\geq 102 \mathrm{~cm}$ for males. Results presented prevalence rates of $26.4 \%$ for overweight, $7.8 \%$ for obesity and $7.5 \%$ for central obesity. There was a significant association between overweight and central obesity with childhood obesity, family history of obesity, and the habitual intake of animal fats. There was a significant association of overweight with the regular intake of alcohol, approximately 3-4 times/week, and less than 2 hours of extracurricular study. The prevalence of overweight among UNIDERP medical students is high and similar to the national population for the same age group.
\end{abstract}

Keywords: Students, Undergraduates, Overweight, Life Habits, Health, Obesity

\section{Introduction}

Overweight and obesity are defined as abnormal or excessive fat accumulation that may impair health [19]. Obesity is a non-contagious chronic disease and its prevalence has become epidemic in recent decades, reaching all age groups and continents. The latest Vigitel Brasil survey, conducted by the Brazilian authorities from the Ministry of Health, show that the obesity rate in the country went from $11.8 \%$ to $19.8 \%$ between 2006 and 2018 showing an increase of $67 \%$. Vigitel also showed that over half of the population $(55.7 \%)$ are overweight, which is an increase of $30.8 \%$ when compared to the $42.6 \%$ in 2006 . The increase in prevalence was higher among the age groups from 18 to 24 years old, with $55.7 \%$. The city of Campo Grande has a frequency of overweight adults of $58 \%$ and an adult obese frequency of $21.5 \%$. [18, 2]
Obesity is a complex disease with a multifactorial etiology. Sedentary lifestyle, excessive and inadequate dietary intake, metabolic, endocrine, psychological, social and cultural factors and poorly known genetic factors related are the main predisposing factors of the disease. Obesity and overweight are accompanied with several different chronic diseases, such as type 2 diabetes mellitus, cardiovascular diseases, dyslipidemias, some cancers and musculoskeletal disorders. It also decreases the quality of life and life expectancy of those affected individuals. [4, 8, 9, 14, 16, 19]

An increased number of academic and extracurricular activities mean negative repercussions and alter the medical students' lifestyle, mainly the ones from the universities that adopt the PBL (Problem Based Learning) method. Due to such high workloads and high dedication, students develop risk factors for weight gain, such as sedentary lifestyle, sleep disorders, behavioral deterioration, anxiety and stress, and etc. $[12,15]$ 
Due to the importance and severity of the disease, it is vital to estimate the prevalence of overweight and central obesity incidence among Uniderp medical students.

\section{Method}

A cross - sectional, quantitative observational study was carried out, which involved 295 both male and female undergraduates, from a universe of 591 - all of them properly enrolled in 2016 first semester at UNIDERP Campo Grande - MS.

The sample size calculation was made considering a $50 \%$ prevalence of overweight, with a $5 \%$ estimation error and a $95 \%$ confidence interval. For a more representative sample, the sample size was increased to 295 , obtaining a sample error of $3.8 \%$.

Besides accepting to participate in the study, and being a properly enrolled undergraduate at UNIDERP, the inclusion criteria was also being able and willing to sign a written informed consent form (ICF).

The exclusion criteria were being pregnant or gestating women for less than six months, having congenital or acquired physical disabilities, and being under the age of 18 years.

The materials used were inelastic metric tapes, stadiometers, Welmy ${ }^{\circledR}$ scales with a variation of $0.1 \mathrm{~kg}$, capacity up to $150 \mathrm{~kg}$, duly calibrated by EBM, following standards control. The completion of the forms and the anthropometric measurements were performed by properly trained researchers, who worked in pairs, and by the participants after signing the acceptance form. The interview and the physical examination were performed at the CEMED outpatient clinic, during weekdays, in the intervals between academic activities.

A structured questionnaire was used for collecting data. The participants filled a questionnaire of 24 sociodemographics questions, including age, gender, marital status, level of education, life habits and lifestyle, and personal history. Anthropometric measurements body weight (in kilograms), height (in meters), body mass index (BMI), and abdominal circumference (AC), in centimeters, were also included in this questionnaire.

Age range was classified in five categories: $18-24$ years, 25-30 years, 31-35 years, 36-40 years and 41-50 years. Physical activity was considered in those who reported regular practice of physical exercise at least 3 times a week and lasting more than 30 minutes per day. The incidence of family history for obesity in first-degree relatives and childhood obesity were evaluated by means of an objective question. The alcohol consumption was evaluated according to the frequency of alcohol consumption and were considered as potential drinkers, those who presented daily consumption and also those who reported alcoholic drink intake of at least three times per week.

The participants were weighed only once, wearing light clothing, barefoot, positioned with both feet on the scale, thus distributing their weight equally on both legs. The height measurement was performed shortly after, in a wall stadiometer, with the volunteer barefoot. The cutoff points for BMI were: overweight $\left(25-29.9 \mathrm{~kg} / \mathrm{m}^{2}\right)$ and obesity $(\geq 30$ $\mathrm{kg} / \mathrm{m}^{2}$ ). Abdominal circumference (AC) was measured in an orthostatic position, with an inelastic tape measuring the midpoint between the last costal arch and the anterosuperior iliac crest during expiration. Male academics with ACs of $102 \mathrm{~cm}$ and females of $88 \mathrm{~cm}$ were considered as having central obesity.

This work has been assessed and approved by the Research Ethics Committee of UNIDERP, under opinion number 1,637,470. All the participants of the research signed the ICF form, after its clarification by the researchers.

The present study is pioneer in the anthropometric evaluation and the abdominal circumference in medical students who study by the PBL methodology. The comparative studies were carried out with institutions of traditional method of Medicine.

\section{Results}

The sample of this study consisted of 295 academics, in which 161 (54.57\%) females and 134 (45.42) males. According to the year of under graduation, $68(23 \%)$ were in their first year, $63(21.35 \%)$ in the second, $75(25.42 \%)$ in the third, $33(11.18 \%)$ in the fourth, $23(7.8 \%)$ in the fifth and 33 $(11.18 \%)$ in the sixth year. In relation to the age group, 238 (80.67\%) students were 18-24 years old, 42 (14.23\%) 25-30 years old, $11(3.72 \%) 31-35$ years old, $2(0,67 \%) 36-40$ and 2 $(0.67 \%) 41$ and 50 years.

The study estimated the anthropometric profile of medical students according to a general prevalence corresponding to: $14(4.7 \%)$ low weight parameter, 180 (61\%) normal parameter, $78(26.4 \%)$ overweight and $23(7.8 \%)$ obesity. In general, most medical students had a BMI within normal range regardless of the year of college they are taking or their gender, as they are shown in the table below.

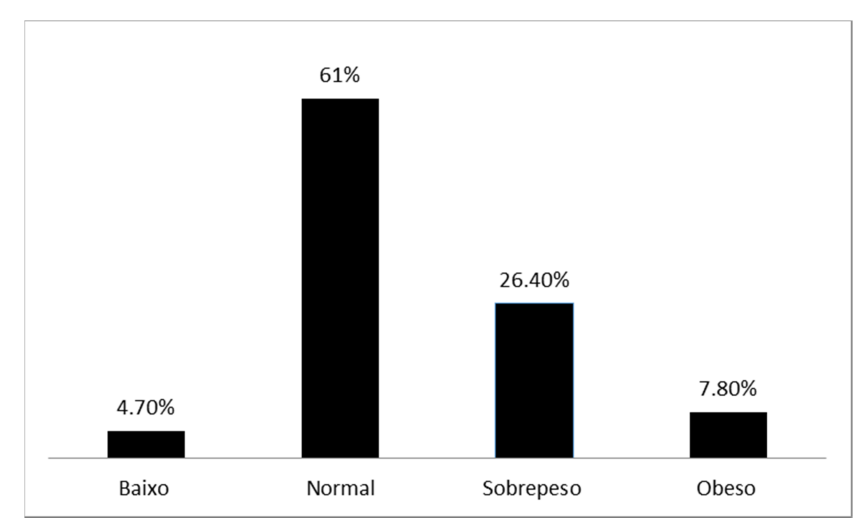

Figure 1. Anthropometric distribution of UNIDERP's School of Medicine undergraduates, 2016.

Table 1 shows the association among variables (obesity in childhood, family history of obesity, smoking habit, alcohol consumption, physical activity, daily study workloads, hours of sleep, marital status, if they live with their parents or not, 
the amount of meals per day, fat consumption, sugary food and fruit and vegetables consumption) and nutritional status according to BMI, and represented by normal/low weight and overweight/obesity.

Table 1. The variables association with the Uniderp medical students anthropometric profile, 2016.

\begin{tabular}{|c|c|c|c|c|c|c|}
\hline \multirow{2}{*}{ Variables } & & \multicolumn{2}{|c|}{ Normal Low Weight } & \multicolumn{2}{|c|}{ Overweight Obese } & \multirow{2}{*}{$\mathbf{P}$} \\
\hline & & $\mathbf{N}$ & $\%$ & $\mathbf{N}$ & $\%$ & \\
\hline \multirow{2}{*}{ Obesity in childhood } & No & 179 & $68,6 \%$ & 82 & $31,4 \%$ & \multirow{2}{*}{$0,005^{*}$} \\
\hline & Yes & 15 & $44,1 \%$ & 19 & $55,9 \%$ & \\
\hline \multirow{2}{*}{ Obesity Family History } & No & 121 & $73,8 \%$ & 43 & $26,2 \%$ & \multirow{2}{*}{$0,002 *$} \\
\hline & Yes & 73 & $56,2 \%$ & 57 & $43,8 \%$ & \\
\hline \multirow{2}{*}{ Smoking } & No & 183 & $67,0 \%$ & 90 & $33,0 \%$ & \multirow{2}{*}{0,105} \\
\hline & Yes & 11 & $50,0 \%$ & 11 & $50,0 \%$ & \\
\hline \multirow[t]{2}{*}{ Alcohol Intake } & Monthly & 58 & $72,5 \%$ & 22 & $27,5 \%$ & \multirow[t]{2}{*}{$0,004 *$} \\
\hline & Weekly & 53 & $53,0 \%$ & 47 & $47,0 \%$ & \\
\hline \multirow{2}{*}{ Physical Exercises } & No & 93 & $62,0 \%$ & 57 & $38,0 \%$ & \multirow{2}{*}{0,166} \\
\hline & Yes & 101 & $69,7 \%$ & 44 & $30,3 \%$ & \\
\hline \multirow{3}{*}{ Daily Study Schedule } & Less 2 hours & 34 & $50,0 \%$ & 34 & $50,0 \%$ & \multirow{3}{*}{$0,002 *$} \\
\hline & 2 hours & 67 & $65,0 \%$ & 36 & $35,0 \%$ & \\
\hline & 3 hours or more & 93 & $75,0 \%$ & 31 & $25,0 \%$ & \\
\hline Hours of Sleep & Less 8 hours & 143 & $66,2 \%$ & 73 & $33,8 \%$ & 0,792 \\
\hline \multirow{2}{*}{ Living with parents } & No & 86 & $61,0 \%$ & 55 & $39,0 \%$ & \multirow{2}{*}{0,099} \\
\hline & Yes & 108 & $70,1 \%$ & 46 & $29,9 \%$ & \\
\hline \multirow{3}{*}{ Meals per day } & Less than 3 & 15 & $65,2 \%$ & 8 & $34,8 \%$ & \multirow{3}{*}{0,348} \\
\hline & $3-5$ & 141 & $63,8 \%$ & 80 & $36,2 \%$ & \\
\hline & 5 or more & 38 & $74,5 \%$ & 13 & $25,5 \%$ & \\
\hline \multirow{4}{*}{ Animal Fat Intake } & No & 69 & $73,4 \%$ & 25 & $26,6 \%$ & \multirow{4}{*}{$0,009 *$} \\
\hline & Yes, $1 \mathrm{X}$ week & 60 & $73,2 \%$ & 22 & $26,8 \%$ & \\
\hline & Yes, $2 \mathrm{X}$ week & 28 & $58,3 \%$ & 20 & $41,7 \%$ & \\
\hline & Yes, $3 \mathrm{X}$ week & 37 & $52,1 \%$ & 34 & $47,9 \%$ & \\
\hline \multirow{5}{*}{ Soft Drinks and fattening/sugary snacks } & No & 21 & $75,0 \%$ & 7 & $25,0 \%$ & \multirow{5}{*}{0,817} \\
\hline & Everyday & 34 & $64,2 \%$ & 19 & $35,8 \%$ & \\
\hline & 3-6 per day & 61 & $67,0 \%$ & 30 & $33,0 \%$ & \\
\hline & $2 \mathrm{X}$ week & 45 & $62,5 \%$ & 27 & $37,5 \%$ & \\
\hline & $1 \mathrm{X}$ week & 33 & $64,7 \%$ & 18 & $35,3 \%$ & \\
\hline \multirow{3}{*}{ Fruits Vegetables Intake } & No & 15 & $78,9 \%$ & 4 & $21,1 \%$ & \\
\hline & Twice per week & 31 & $62,0 \%$ & 19 & $38,0 \%$ & \\
\hline & Once per week & 17 & $73,9 \%$ & 6 & $26,1 \%$ & \\
\hline
\end{tabular}

$* \mathrm{p} \leq 0,05=$ statistically significant.

According to the table above, there was a significant association between overweight and family history of obesity in first-degree relatives $(p=0.002)$, childhood obesity $(p=$ $0.005)$ and animal fat intake $(p=0.009)$. Another significant association was about the frequency of alcohol consumption and the anthropometric profile $(\mathrm{p}=0.004)$, where higher consumption (daily or 3-4 times a week) reached $47 \%$ of overweight/obese students compared to $27.8 \%$ rare consumption. In addition, there was a significant association between the consumption of animal fat and the anthropometric profile $(\mathrm{p}=0.009)$, showing that $47.9 \%$ of obese/overweight consume animal fat 3 times a week, whereas $26.8 \%$ consume once a week. There was also a significant association between daily study hours and the anthropometric profile $(\mathrm{p}=0.002)$, which shows that $25 \%$ of overweight/obese studied 3 hours or more, whereas $50 \%$ studied less than 2 hours, which was a surprising result. On the other hand, there was no significant association between the other variables and the anthropometric profile.

Regarding central obesity, in the analysis of the total sample of this research, a prevalence of $7.4 \%$ was observed in Uniderp's medical students, where 22 students had increased AC and 273 academics (92.6\%) had a AC below the value for central obesity in this study $(\geq 102 \mathrm{~cm}$ for men and $\geq 88 \mathrm{~cm}$ for women). These values are represented in Figure 2.

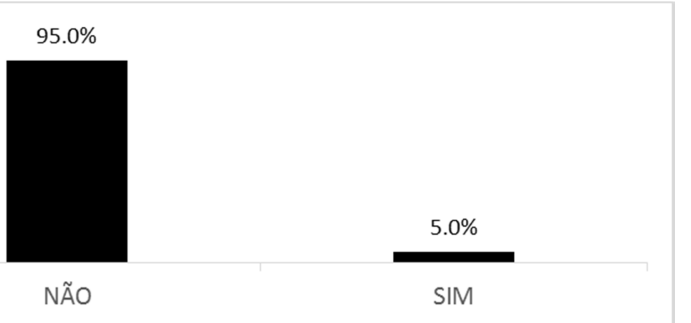

Figure 2. Central obesity among medical students at UNIDERP in Campo Grande/MS, 2016.

Taking into consideration the association between the variables (obesity in childhood, obesity in the family, smoking 
habit, alcohol consumption, physical activity, daily study hours, sleep hours, parents' morbidity, animal fat consumption) and central obesity, abdominal circumference, there was a significant association between the history of childhood obesity and the measure of abdominal circumference $(p=0.007)$. Seven out of 27 students who presented childhood obesity (20.6\%) remained obese. Another significant association was the "Obesity in the family" variable $(p=0.009)$. Fifteen out of 115 students with obese relatives $(11.5 \%)$ had abdominal circumference number higher than normal. There was also a significant association with the variable animal fat intake $(p=0.001)$. Only two out of 80 academics who reported consuming animal fat once a week (2.4\%), had the measurement of abdominal circumference above normal. Seventeen out of 102 who reported consuming animal fat 2 times a week (14.3\%) presented abdominal circumference measurement above normal. The other variables (smoking, alcohol consumption, physical activity, hours of daily study, workloads, hours of sleep and parents' morbidity) were not significant when compared to the measurement of abdominal circumference.

\section{Discussion}

The prevalence of overweight and obesity in the research was higher than that of the population of UFSC's undergraduate medical students, which was $17 \%$ and $1 \%$, respectively [11]. It was also higher when compared to a study in a population of medical students from a private college in Vitória, (ES), in which a prevalence of $1.4 \%$ of obesity has been observed [1]. Another study performed with the adult population of 20-59 years from Lages (SC), in 2008 , showed an overall prevalence of $23.5 \%$ of obesity [16]. The study performed with the adult population aged $20-59$ years in Santo Ângelo, (RS) estimated a prevalence of $16.6 \%$ [7]. Both data demonstrated similarity with the results of the research and the age group mostly studied. Comparing data at the national level, the Vigitel 2018 study observed a prevalence of $55 \%$ of overweight in the general population from 18 years; of these, $19.8 \%$ are obese [2]. The results of the prevalence of overweight in the study corroborate with the findings of the national population.

The prevalence of central obesity in the present study was lower than that of the population from UFSC's research that was $14 \%$. Another study carried out with university students from Curitiba (PR), also registered a higher rate of central obesity, in which $24.4 \%$ of the students had abdominal circumference above normal levels [10].

In the research was observed a significant association of overweight in the students who had a daily consumption of alcohol or consumption between 3-4 times per week. Compared with the study with the UFSC medical students, it was observed that $16.6 \%$ of overweight individuals are abstemious and $55.5 \%$ have less than 5 occasions of consumption per month. Although the data are different, both indicate a significant association between alcohol consumption and excess weight.

The animal fat intake of three or more times per week increased the incidence of overweight in Uniderp medical students and had no significant association with central obesity. Diet patterns are important for weight control. Exaggerated consumption of animal fat leads to weight gain, since $1 \mathrm{~g}$ of fat contains 9 calories, whereas the same amount of carbohydrates and proteins have 4 calories. The results of the Vigitel research on the food and diet habits among the population in Campo Grande are alarming. Campo Grande presented the highest level of skin and fat of chicken meat consumption and fattening red meat (47.7\%), 56.5\% corresponding to males and $39.7 \%$ females, being even higher among those of the age range of 18-44 years in both genders [3].

Being an obese child and having a family history of obesity (first degree) increased the prevalence of overweight and central obesity in Uniderp medical students. This association is based on scientific research and observed in several studies with different age groups, as observed in VEDANA, et al., 2008; OLIVEIRA, et al., 2009; GABAN, S., 2013.

The other variables analyzed in the study had no significant association with overweight and central obesity, as they did not present significant statistical results.

According to the results of the study, there is a high prevalence of overweight in academics. Thus, actions willing to curb the spread of this disease and its comorbidities should be suggested and implemented in their own educational institutions, such as: a partnership with the universities' cafeterias, by offering less caloric healthier foods; partnerships with other graduation courses, such as Physical Education and Nutrition, so that the adaptations regarding the habits of life are stimulated. In the case of full-time course in which many students stay in college (do not return home and irregular diet habits), these actions would be important in the improvement of the students' quality of life.

Medical students who participated in this survey who had $\mathrm{BMI} \geq 25$ and increased waist circumference were alerted to the find and told to seek guidance with qualified professionals in different areas (endocrinologists, nutritionists, psychologists, physical educator, etc.)

The follow-up of the academics who participated in this work should be continued, in which they must have the weight and AC checked annually until the conclusion of the course. With these anthropometric measurements and body fat distribution of students from the first to the last year of Uniderp's medical school, it is possible to get consistent results, related to the association of overweight and central obesity, with the methodology in this study, and also a comparison with the results of the same study carried out in medical students in the traditional course.

\section{Conclusion}

The present study showed that the prevalence of overweight and obesity in UNIDERP medical students achieved results similar to those of most studies on the national population, which consists of the high prevalence of overweight.

Considering the association between overweight and 
central obesity with some variables, a significant difference was observed in three cases: family history of obesity, obesity in childhood and consumption of animal fat.

There was a significant association of overweight with daily consumption or 3-4 times per week of alcoholic beverage and extracurricular daily study less than 2 hours.

In the present study, there was no association of overweight and central obesity with physical activity, smoking habits, consumption of fattening snacks and soft drinks, consumption of fruits and vegetables, sleep/night hours, living with parents and the number of daily meals.

\section{Acknowledgements}

Firstly, thanks to God, the Almighty's author. Thanks to our families and the professors involved in the process, who have always supported and assisted us. This research has been developed with the authors' own resources.

\section{Appendix}

Article Questionnaire Form

\section{Survey Participants Profile}

Full Name

Home Address

Phone number

Natural from (city)

Gender:

( ) Male ( ) Female

For women only: Are you a parent?

( ) No. ( ) Yes, of 1 kid ( ) 2 kids ( ) 3 kids or more

College Semester you are taking:

Age (years old):

( ) $1.18-24$ ( ) $2.25-30$

( ) $3.31-35$ ( ) $4.36-40$

( ) 5. 40-50 anos

Do you live with your parents?

( ) Yes ( ) No

Number of people who live with you:
( ) 1. One ( ) 2. Two
( ) 3. Three ( ) 4. Four
( ) 5. Five ( ) 6. Five or more;

\section{Lifestyle and Habits}

Do you exercise very regularly?

( ) 1. Yes ( ) 2 . No

(If affirmative) How often do you exercise?

( ) 1 . Once a week

( ) 2. Twice a week

( ) 3. Three times a week

( ) 4. More than three times a week

When you exercise, how long does it take?

( ) 1. Up to 30 minutes ( ) 2. Minimum of 30 minutes

How much time do you spend studying every day?
( ) 1 . Up to 1 hour
( ) 2.1 hour
( ) 3. Two hours
( ) 4. minimum three hours

How many hours of sleep do you get?

( ) 1. Less than 8 hours

( ) 2.8 hours 
( ) 3. More than 8 hours

Is there any case of obesity in your family? (parents, kids, siblings, grandparents)

Were you obese in your childhood?

( ) 1. Yes ( ) 2. No

Do you smoke regularly?

( ) 1. Yes ( ) 2. No

If affirmative, How much?

( ) 1. Up to half a pack ( ) 2. Up to one pack ( ) 3. Minimum of one pack

Do you drink alcoholic beverages regularly?

( ) 1 . Yes, every day.

( ) 2. 3-5 times a week

( ) 3. 1-2 times a week

( ) 4. 1-2 times a month

( ) 5. Rarely

\section{Dietary Habits}

How many meals do you have a day?

() 1 . Up to 3

() $2.3-5$

() 3. Minimum 5

Do you eat animal fat (chicken skin, red fattening meat, etc.) and how often?

( ) Never ( ) Yes, once a week ( ) Yes, twice a week. ( ) Yes, minimum of three times a week.

Do you eat fruits and vegetables? How often?

( ) Never ( ) Yes, every day. ( ) Yes, 3-6 times a week ( ) Yes, 2 times a week.

( ) Yes, once a week.

Do you have soft drinks and sugary/fattening snacks)? How often?

( ) Never. ( ) Yes, every day. ( ) Yes, 3-5 times a week. ( ) Yes, 2 times a week.

( ) Yes, once a week.

\section{Clinical Assessment}

Weight:

\begin{tabular}{|l|}
\hline \\
\hline Height: \\
\hline
\end{tabular}

BMI (Body Mass Index):

Abdominal Circumference (standing):

\section{References}

[1] Brandão, C. D. G.; Cunha, F. G. C. Obesidade e fatores de risco associados em alunos de medicina de uma faculdade privada de Vitória-ES. Revista da Associação Brasileira de Nutrição: Vol. 4. Num. 5. 2012.

[2] Brazil. Ministry of Health. Health Surveillance Secretariat. Department of Health Analysis and Disease Surveillance not transferable. Vigitel Brazil 2018: surveillance of risk factors and protection for chronic diseases by telephone survey: estimates on frequency and sociodemographic distribution of risk and protective factors for chronic diseases in the capitals of the 26 Brazilian states and the Federal District in 2018/Ministry of Health, Health Surveillance Secretariat, Department of Health

Analysis and Surveillance of Noncommunicable Diseases. Brasilia: Ministry of Health, 2019.

[3] Brasil. Ministério da Saúde. Secretaria de Vigilância em Saúde. Vigitel Brasil 2011: Vigilância de Fatores de Risco e Proteção para Doenças Crônicas por Inquérito Telefônico. Ministério da Saúde, Secretaria de Vigilância em Saúde, Brasília: Ministério da Saúde, 2012. (Série G. Estatística e Informação em Saúde).

[4] Cornier, M. A.; e colaboradores. The metabolic syndrome. Endocrine Reviews. Vol. 29. Num. 7. p. 777-822. 2008.

[5] Gaban, S. C. N. Excesso de peso e obesidade central em população adulta urbana - fatores associados e doenças relacionadas ao risco cardiovascular. Disponível em: http://repositorio.cbc.ufms.br:8080/jspui/handl e/123456789/1916 
[6] Linhares, R. S. e colaboradores. Distribuição de obesidade geral e abdominal em adultos de uma cidade no sul do Brasil. Cadernos de Saúde Pública, [S. 1], v. 28, n. 3, Mar. 2012.

[7] SARTURI, Juliana Barbosa; NEVES, Janaina das; PERES, Karen Glazer. Obesidade em adultos: estudo de base populacional num município de pequeno porte no sul do Brasil em 2005. Ciênc. saúde coletiva, Rio de Janeiro, v. 15, n. 1, p. 105-113, Jan. 2010.

[8] Leeners B, Geary N, Tobler PN, Asarian L. Ovarian hormones and obesity. Hum Reprod Update 2017; 23: 300-21.

[9] Mancini, M. C. e colaboradores. Obesidade e Doenças associadas. In: Tratado de Obesidade. Itapevi: AC Farmacêutica. p. 253264., 2010.

[10] MARIANO, K. G. T. S.; FERREIRA, S. G. S.; AMARAL, I. C.; OLIVEIRA, L. C. Identificação de fatores de risco para o desenvolvimento de síndrome metabólica e doença cardiovascular em estudantes universitários. Cadernos da Escola de Saúde, v. 2, n. 10, p. 50-62, 2013.

[11] Marques, M. O. T. Prevalência de obesidade e sobrepeso em acadêmicos do curso de graduação em Medicina da Universidade Federal de Santa Catarina. Arquivos Catarinenses de Medicina. Vol. 38. Num. 1. 2009.

[12] Mota, M. C.; e colaboradores. Estilo de vida e formação médica: impacto sobre o perfil nutricional. Revista Brasileira de Educação Médica. Vol. 36. Num. 3. p. 358-368. 2012.
[13] Oliveira, L. P. M.; e colaboradores. Fatores associados a excesso de peso e concentração de gordura abdominal em adultos na cidade de Salvador, Bahia, Brasil. Cad Saúde Pública. Vol. 25. p. 570-582. 2009.

[14] Pavelka, J. C.; e colaboradores. Morbid obesity and endometrial cancer: surgical, clinical, and pathologic outcomes in surgically managed patients. Ginecology Oncology. Vol. 95. Num. 3. p. 588-592. 2004.

[15] Smolka, M. L. R. M.; Gomes, A. P.; Siqueira-Batista, R. Autonomia no contexto pedagógico: percepção de estudantes de medicina acerca da aprendizagem baseada em problemas. Revista Brasileira de Educação Médica. Vol. 38. Num. 1. p. 514. 2014.

[16] Vedana, E. H. B.; Peres, M. A.; Neves, J.; Rocha, G. C.; Longo, G. Z. Prevalência de obesidade e fatores potencialmente causais em adultos em regiao do sul do Brasil. Arquivos Brasileiros de Endocrinologia e Metabologia. Vol. 52. Num. 7. p. 1156-1162. 2008.

[17] Vilares, S. M. F.; Mancini, M. C. Obesidade. In: Saad, M. J. A.; Maciel, R. M. B.; Mendonça, B. B. (Org.). Endocrinologia. Atheneu. 2007. cap. 48. p. 1001-1021.

[18] WHO. World Health Organization. World healthstatistics 2014.

[19] World Health Organization (WHO). Obesity and overweight [Internet]. WHO; 2019. [cited 2018 Feb 16]. Available from: https://www.who.int/news-room/fact-sheets/detail/obesityand-overweight. 